\title{
A drámapedagógia alkalmazási lehetőségei a korai idegen nyelvi fejlesztésben
}

\author{
Sárvári Tünde \\ Szegedi Tudományegyetem Juhász Gyula Pedagógusképző Kar
}

\begin{abstract}
A drámapedagógia mint módszer egyre szervesebb részévé válik a magyar köznevelésnek. Ennek egyik oka, hogy ez a „pezsgőtabletta” minden tantárgy esetében sikerrel alkalmazható, és lehetővé teszi a gyermekek holisztikus nevelését, ami az alsó tagozaton különösen nagy jelentőséggel bír.

A tanulmány célja megvizsgálni és bemutatni, hogyan alkalmazható a drámapedagógia a korai német mint idegennyelv-tanitás egyik speciális fázisában, az ún. szóbeli kezdőszakaszban, ahol a tanulók még az idegen nyelvü olvasás és írás bevezetése előtt állnak. Ehhez a drámafoglalkozásokra jellemző három nagy szakasz (warm up, action, sum up) alapján csoportositva olyan dramatikus tevékenységek kerülnek bemutatásra, melyek eredményesen alkalmazhatóak az adott célcsoport idegen nyelvi fejlesztésében.
\end{abstract}

Kulcsszavak: korai idegen nyelvi fejlesztés, német nyelv, szóbeli kezdőszakasz, drámapedagógia, holisztikus nevelés

\section{Bevezetés}

A dráma, a drámapedagógia napjaink magyarországi oktatási rendszerének szerves részévé vált. A vélemények ugyan megoszlanak a tekintetben, hogy mi is a dráma, illetve a drámapedagógia. Van, aki tantárgynak tekinti, hiszen a NAT (2012) is szabadon választható tantárgyként ajánlja az alsó tagozatban, illetve a felső tagozat ötödik évfolyamán. Mások szerint a dráma egy módszer, ami a legtöbb tevékenységbe bevihető, minden tanórán jelen lehet. Czike (2012. 66. o.) a drámát olyan „pezsgőtablettának” nevezi, „ami bármely folyadékban feloldódik”, ami egyfajta „katalizátor”.

A tanulmány célja megvizsgálni és bemutatni, hogyan alkalmazható a drámapedagógia a korai német mint idegennyelv-tanítás egyik speciális fázisában, az ún. szóbeli kezdőszakaszban, ahol a tanulók még az idegen nyelvű olvasás és írás bevezetése előtt állnak. Témaválasztásomban egyrészt Schewe (1993. 185. o.) gondolata motivált, mely szerint akkor beszélhetünk kommunikatív nyelvoktatásról, ha a nyelvórán dramatikus tevékenységeket alkalmazunk, másrészt felmerült bennem a kérdés, hogyan adaptálhatóak saját drámapedagógiai tanulmányaim a korai idegen nyelvi fejlesztésben.

Ahhoz, hogy választ kapjunk a feltett kérdésekre, először meg kell vizsgálni, mik tartoznak a dramatikus tevékenységek körébe, és hogyan rendszerezhetőek az említett tevékenységek. A bemutatáshoz egyrészt Gavin Bolton (1994) rendszerezését, másrészt a magyarországi gyakorlatot is figyelembe vevő, Takács Gábor (2008) által összegyűjtött típusokat mutatom be és hasonlítom össze röviden.

Mivel vizsgálódásom középpontjában a nyelvoktatás egy speciális területe, a korai idegen nyelvi fejlesztés áll, rávilágítok e terület néhány sajátosságára (cél, tartalom, ajánlott tevékenységi formák, eszközök, médiumok, fejlesztési követelmények). A NAT (2007. 2012. o.) nem fogalmaz meg konkrét fejlesztési követelményeket az 1-3. évfolyam idegennyelv-tanításával kapcsolatban, ezért a témakör bemutatásánál 
a Világ-Nyelv Programban 2004-ben kidolgozott ajánlásra (Kuti et al., 2004), illetve a korai nyelvoktatással foglalkozó ún. Nürnberger Empfehlungen átdolgozott változatára (Widlok, 2010) támaszkodom.

A harmadik rész olyan dramatikus tevékenységeknek a bemutatását és leírását tartalmazza lépésröl lépésre, melyek eredményesen alkalmazhatóak a korai idegen nyelvi fejlesztés során. A tevékenységeket a Pinczésné (2003. 21.) által is említett, a drámafoglalkozásokra jellemző három nagy szakasz (warm up, action, sum up) alapján csoportosítom és mutatom be.

\section{1. „A drámapedagógia a pedagógia müvészete”}

A fejezet címe Móka János 'drámapedagógia-definíciója' (idézi Szabó-Thalmeiner 2011: 5). Ha ennél tudományosabb igényű meghatározást keresünk, leggyakrabban a Pinczésné (2003. 33. o.) által megfogalmazott definíciót olvashatjuk: a drámapedagógia „a személyiség fejlesztésének olyan módszere, amelynek során az egyén ismeretei, készségei, képességei, társas kapcsolatai a nevelő (drámatanár) által irányított, csoportban végzett közös dramatikus cselekvés révén fejlődnek."

Pinczésné (2003. 5. o.) hangsúlyozza a drámapedagógia interdiszciplináris jellegét, ahol több tudomány és múvészet gyakorol hatást egymásra (1. ábra):

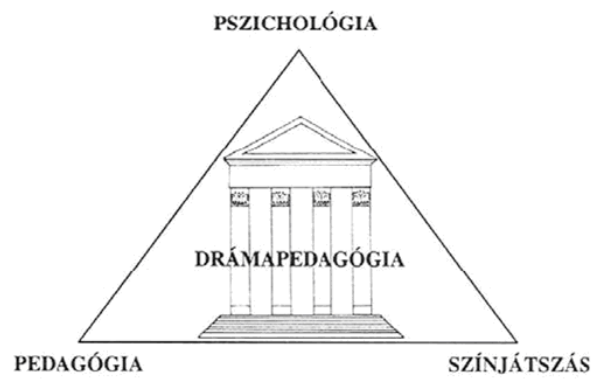

1. ábra: A drámapedagógiai gyökerei (Pinczésné, 2003. 5. o.)

Az 1. ábra jól szemlélteti, hogy a drámapedagógia gyökerei egyaránt fellelhetőek a színművészetben, a pedagógiában és a pszichológiában. A drámapedagógia a színművészettől 'örökölte' a drámai megjelenítés módjait, funkcióit; a pedagógiától a reformpedagógia egyes aspektusait (Montessori, Freinet, Steiner, Rogers, Gordon); a pszichológiától pedig a fejlődéslélektan játékkal kapcsolatos elméleteit (Piaget, Mérei), illetve a pszichodrámából ismert csoportmódszereket (Moreno).

A magyar drámapedagógia jeles képviselője Kaposi László (2008. 3. o.) a drámapedagógia alatt egy „a drámán keresztül történő nevelés” tudományát és gyakorlatát, vagyis a „drámára épített pedagógiát” érti. Nézetei szerint a dráma olyan „csoportos játéktevékenység, melynek során képzeletbeli (fiktív) világot építenek fel, ebbe a képzeletbeli világba a résztvevők szereplőként vonódnak be, a fiktív világon belül valós problémákkal találkoznak, s ebből valós tudásra tesznek szert”. Véleménye szerint a színház az, amitől nem lehet elválasztani a drámát, mert a dráma a színház nyelvén beszél, és a drámaórán játszó gyermek a színjátszó csoportban játszó társával szemben nem azért játszik, hogy a közönségnek közvetítsen valamilyen tartalmat, hanem azért, hogy saját maga élje meg, illetve tapasztalja meg a szerepet (vö. Kaposi, 2008. 24. o.).

Mindkét megfogalmazás közös eleme a csoport, a közösen végzett dramatikus tevékenység, mely a személyiség fejlesztését eredményezi. Tekintsük át, mik tartoznak az említett dramatikus tevékenységekhez, és hogyan lehet rendszerezni őket! 


\subsection{A dramatikus tevékenységek rendszerezése Gavin Boltonnál}

A dramatikus tevékenységek legismertebb rendszerezése Gavin Bolton nevéhez füzödik. Bolton négy csoportot sorol fel (1993. 12-19.):

- „A” típus: gyakorlatok

- „B” típus: dramatikus játék

- "C” típus: színház

- „D” típus: a megértést szolgáló/tanítási dráma.

Bolton (1993. 12-14.) a jellemző tulajdonságok alapján az „A” típus, azaz a gyakorlatok öt fajtáját különbözteti meg:

1. közvetlen tapasztalatszerzés

2. dramatikus készségfejlesztés

3. helyzetgyakorlatok

4. játékok

5. egyéb müvészetek formanyelvének bevonása.

A gyakorlatokat tehát meghatározott cél érdekében, bizonyos készségek fejlesztésére alkalmazhatjuk. A gyakorlatok rövidek, ismételhetőek és kötött szabályok szerint müködnek.

A „B” típusba a dramatikus játékok tartoznak, melyek nyitott kimenetelü, szerkesztetlen improvizációk, ahol a gyermekek szerepben vannak. Ez a dramatikus tevékenység hasonlít legjobban a kisgyermekkori dramatikus játékhoz.

A „C” típus talán sokak számára az ismerősnek tűnő fajta, ahol egy megtanult, begyakorolt, közönség előtt bemutatott produkcióról van szó.

A „D” típust Bolton megértési drámának vagy tanítási drámának nevezi, amely mindhárom előzőleg leírt drámajáték-típust magában foglalja, ötvözi. Ez a komplexebb forma azt célozza, hogy a játszók az eljátszott témát vagy problémát jobban megértsék, ezért nevezte Bolton a „D” típust megértési drámának.

\subsection{A dramatikus tevékenységek rendszerezése Takács Gábornál}

Takács Gábor (2008. 32-37.) egy az utóbbi évek szakirodalma, valamint a magyarországi gyakorlat tapasztalatai alapján továbbfejlesztett tipológiát ír le:

- „A" típus: Gyakorlatok

- "B” típus: Dramatikus játék

- "C” típus: Színházi forma

- „D” típus: Tanítási (komplex) dráma

- „E” típus: Szakértői dráma

- F” típus: Színházi nevelési program

Meg kell említeni, hogy az osztályozás nem sorrendiséget jelent; mert mint Takács (2008. 32. o.) is utal rá, „mindegyik típusnak vannak előnyei és hátrányai. Bármely típus kizárólagos használata csökkenti a dráma oktatásban való alkalmazhatóságának lehetőségeit".

Takács (2008. 32. o.) felosztásában az „A” típusba, a gyakorlatokhoz két nagy játékcsoport került, a szabályjátékok és a helyzetgyakorlatok. A gyakorlatok legfontosabb jellemzői (2003. 33. o.) nagy hasonlóságot mutatnak a Bolton által megnevezett ismérvekkel.

Mint arra Takács (2008. 32. o.) is rámutat, a szabályjátékok napjainkra a 'közkincs' kategóriába tartoznak, mert sok esetben a pedagógusok nincsenek tisztában az alkalmazott játék forrásával, eredetével, csak 'használják'. A legtöbb Magyarországon megjelent játékgyűjtemény is sok szabályjátékot tartalmaz, mert ezek a játékok szórakoztatóak, jól alkalmazhatóak a közösség- és személyiségépítő folyamatok megköny- 
nyítésére, fejlesztésére. A szabályjátékok nagy segítséget nyújthatnak az alsó tagozatos korosztálynál végzett fejlesztő munkában, a csoport munkára hangolásakor, vagy a tanítási drámán belüli alkalmazásukkor.

Meg kell azonban jegyezni, hogy Kaposi (2008. 3. o.) szerint a szabályjátékok nem tekinthetők drámának ${ }^{1}$, mert „a képzeletbeli világnak nyomelemei sem jelennek meg bennük, a résztvevők nem másokat játszanak, hanem önmagukat, csak kissé furcsa körülmények között".

A helyzetgyakorlatok esetében a szabályjátékoknál kötöttebb formáról van szó, hiszen ezek a játékok sokszor problémamegoldó formát öltenek, továbblépési lehetőséget kínálnak a szituációs játékok, a színházi forma felé. Takács $(2008,33)$ felhívja a figyelmet arra, hogy „,a helyzetgyakorlatok indításához és irányításához nem árt tisztában lennie a tanárnak a szituáció megadásának elméletével és gyakorlatával".

A „B” típusról, a dramatikus játékról azt írja Takács (2008. 33. o.), hogy lényegét tekintve a gyermeki 'mintha' játékkal nagyon közel állnak egymáshoz. A dramatikus játék az iskolai keretek között működik, és azt mind a tanár, mind a tanulók drámaként értékelik. A dramatikus játék véleménye szerint felfogható „alulhatározott szituációként" is (Takács, 2008. 33. o.), mert: a szituáció elemei közül általában a helyszín, az idő és probléma van megkötve. Takács (2008. 33.) utal arra, hogy a dramatikus játék oktatási hasznosíthatósága nem túl jelentős, mert „a játékbeli szabadság nagyon magas foka miatt általában csak „müfajváltással” (vagy szerencsével) lehet elérni egy meghatározott tanulási területet”. „Tiszta változataiban” elsősorban az alsó tagozat elején alkalmazhatóak eredményesen.

A „C" típus, a színházi forma is ismerős a pedagógusoknak, mert szinte minden köznevelési intézményben kell műsort vagy előadást készíteni a gyermekekkel.

A „D” típus, a tanítási dráma, amely az angolszász területekről a 90-es években hazánkba is elért drama in education (DIE) vagy educational drama elmélete és gyakorlata, amely azóta bővült, változott (lásd Kaposi drámadefiníciója 2008. 3. o.).

A már ismert boltoni felosztást Takács két újabb típussal ( $E$ és $F$ ) egészíti ki. Az „E” típus, a szakértői dráma, mely Takács (2008. 35. o.) definíciója szerint „a tanítási dráma alkalmazásának komplex, több tanóra alatt, a gyakorlatban általában sorozatok formájában megvalósítható, elsősorban tantárgyi ismeretek átadását, rendszerezését, mélyítését segítő módja". A szakértői dráma megalkotója Dorothy Heathcote, aki sokszor tapasztalta, hogy a 'tanár szerepben' technikával nem minden esetben lehet bevonni a gyermekeket a drámába. A probléma megoldását egy új drámás technikában, az ún. 'szakértő köntösében' vagy 'szakértői játékban' vélte felfedezni. Ennél a technikánál a tanár az adott probléma szakértőjének szerepét kínálja fel a csoportnak. Ugyancsak Heathcote nevéhez füződik az a megállapítás, hogy a drámapedagógia sikeresen alkalmazható más tantárgyak tanítására is (vö. Sz. Pallai, 2003. 85-86.).

Az „F” típus, a színházi nevelési program, melynek célja a színházi nézővé nevelés (színházra nevelés) mellett a színházzal nevelés is. Takács (2008. 36. o.) véleménye szerint ez a program a magyarországi gyakorlatban „összesüríti mindazokat a formákat, amelyek legfőbb közös jellemzője, hogy a színházi előadást megelőzően vagy követően, esetleg az előadás közben a fiatal nézők túllépnek a hagyományos nézői szerepkörön és valamiféle interaktivitás jön létre az alkotók és a befogadók közt".

\footnotetext{
1 Kaposi (2008. 3. o.) meghatározása szerint a dráma „olyan csoportos tevékenység, amelynek során képzeletbeli (fiktív) világot építünk fel, ebbe a képzeletbeli világba a résztvevők szereplőként vonódnak be, a fiktív világon belül valós problémákkal találkoznak, s ebből valós tudásra és tapasztalatra tesznek szert".
} 
A színházi nevelés gyökerei is Angliában találhatók. A 60-as években közös gondolkodásra hívó, interaktív színházi előadásokat tartottak iskolai csoportoknak. Ennek a múvészetpedagógiai eljárásnak Theatre in Education (TIE) volt a neve. Ehhez az irányzathoz tartozik az Augusto Boal nevével fémjelzett Fórum Színház tevékenysége is. Magyarországon a TIE két legjelesebb képviselője a korábban Kaposi László vezette Kerekasztal Színházi Nevelési Központ és a Takács Gábor által irányított Káva Kulturális Mühely.

\section{A kisiskoláskori idegennyelv-oktatás sajátosságai}

Napjainkban a használható idegennyelv-tudás egyre nagyobb szerepet játszik a mindennapi életben is. A felfokozott társadalmi igény és az ebből fakadó egyre nagyobb szülői nyomás eredményeként az idegennyelv-tanulás kezdete egyre korábbi időpontra került. A 2007-es és a 2012-es NAT értelmében az első idegen nyelv oktatása legkésőbb az általános iskola negyedik évfolyamán kezdődik, de ha megfelelő végzettségü pedagógus alkalmazása megoldható, és az iskola pedagógiai programja erre lehetőséget ad, az első idegen nyelv oktatása az 1-3. évfolyamokon is megkezdhető.

Az élő idegen nyelv müveltségi terülten belül több tantárgyról beszélünk, hiszen ehhez a müveltségi területhez több idegen nyelv is tartozik. A NAT $(2007,2012)$ a különböző idegen nyelveket egységes területként kezeli, csak az első és második idegen nyelv között tesz különbséget, ha szükséges. A NAT $(2007,2012)$ a fejlesztési feladatok meghatározásánál három szakaszt különít el: a kötelező kezdésre építve a 4., az 5-8. és a 9-12. évfolyamokat. A fejlesztési feladatok minden, a Közös Európai Referenciakeretben (KER, 2002, 27-54.) meghatározott nyelvelsajátítási szinten (A1, A2, B1, B2, C1, C2) a receptív (beszédértés, olvasásértés) és a produktív (beszédkészség, írás) készségek fejlesztését foglalják magukba. Az általános iskola végére a NAT (2012) minden diák számára előírja legalább egy élő idegen nyelvből az A2-es, azaz az európai alapszint elérését.

Az élő idegen nyelv műveltségi terület, ezen belül pedig a német nyelv tantárgy céljai és tartalma összhangban állnak a NAT $(2007,2012)$ többi müveltségi területének céljaival, tartalmával, és az Európa Tanács ajánlásaival. A nyelvtanulás folyamata a NAT $(2007,2012)$ bevezetőjében megfogalmazott kulcskompetenciákra épül. Az idegen nyelv tanulásának és tanításának elsődleges célja a kommunikatív idegen nyelvi kompetencia kialakítása és fejlesztése.

A nyelvoktatáson belül különbséget kell tennünk a kisgyermekkori idegennyelvoktatás/elsajátítás (az óvodai idegen nyelvi neveléstől az általános iskola negyedik évfolyamának végéig terjedő időszak), illetve a későbbi idegennyelv-oktatás között. Tekintsük át a kisiskoláskori, azaz 1-4. évfolyamon történő idegennyelv-tanítás sajátosságait! A sajátosságokat öt szempontból mutatom be:

1. cél

2. tartalom

3. tevékenység

4. eszköz

5. fejlesztési követelmények.

A szempontok kiválasztásánál a $\operatorname{NAT}(2007,2012)$, a Kerettanterv $(2004,2012)$, az 1-3. évfolyam számára kidolgozott idegen nyelvi program (Kuti, 2004) és a Nürnbergi ajánlások (Widlok, 2010) előírásait, illetve ajánlásait tartottam szem előtt. 


\subsection{A kisiskoláskori idegennyelv-oktatás céljai}

A legkésőbb a 4. évfolyamon kezdődő kisiskoláskori idegennyelv-tanítás elsődleges célja a tanulók idegen nyelvi kommunikatív kompetenciájának megalapozása, illetve a tanulók érdeklődésének felkeltése a nyelvek tanulása és a más nyelveket beszélő emberek és kultúrájuk megismerése iránt (Kerettanterv, 2004, 2012).

A NAT $(2007,2012)$ és a Kerettanterv $(2004,2012)$ a 4. évfolyam végére határoz meg először célokat és fejlesztési követelményeket. Az 1-3. évfolyamosok idegennyelv-oktatásával kapcsolatosan az Oktatási Minisztérium megbízásából 2004-ben, a Világ-Nyelv Program keretében készült el Kuti Zsuzsa irányításával egy magyar nyelvű ajánlás (Idegen nyelvi program az 1-3. évfolyam számára. Ajánlás a 6-9 éves korosztály idegennyelv-tanításához ${ }^{2}$ ), de fontos elveket tartalmaz a müncheni Goethe Intézetben Beate Widlok vezetésével 2010-ben átdolgozott és aktualizált Nürnberger Empfehlungen zum frühen Fremdsprachenlernen (Korai idegennyelv-tanulás - „Nürnbergi ajánlások") című kiadvány is.

Kuti és munkatársai (2004. 4. o.) rámutatnak, hogy az idegen nyelvvel való korai ismerkedés alapvető célja „kedvet ébreszteni a nyelvek tanulása és más népek kultúrájának megismerése iránt, hozzájuttatni a kisgyermeket a többnyelvűség élményéhez, valamint a játékos tanulás során szerzett kezdeti sikerek kíséretében megalapozni a későbbi nyelvtanulást".

A készségfejlesztés szempontjából a kisgyermekkori idegennyelv-tanítás középpontjában a hallott szöveg értése és a szóbeli interakció együttes fejlesztése áll. A hallott szöveg értésének fejlődését nyomon követhetjük az órai utasítások és a cselekvésre épülő játékos feladatok teljesítéséből. A beszéd az egyszavas válaszoktól (igen, nem, név, szín, szám stb.) a memorizált, elemezetlen nagyobb egységek használatáig terjed (köszönés, mondóka, körjáték, dal). A gyermekek órai beszédének természetes része a magyar nyelvü kérdés és válasz, melyet visszajelzésként, megerősítésként használnak a tanár célnyelvhasználatával párhuzamosan. A kisiskoláskori idegennyelv-tanítás során az olvasás és írás bevezetésével célszerű várni, míg a gyermekekben felmerül erre az igény (vö. Kerettanterv, 2004, 2012).

A Nürnbergi ajánlásokban (Widlok, 2010. 24. o.) is megfogalmazásra kerül, hogy a kisiskoláskori idegennyelv-oktatás során a nyelvi kompetenciák fejlesztésén túl nagy hangsúlyt kell fektetni az általános, az interkulturális és a tanulásstratégiai képességekre is. Az Ajánlás értelmében az alábbi általános kompetenciák fejlesztésére kell lehetőséget biztosítani az idegennyelv-oktatás során (Widlok, 2010. 25. o.):

- a beszélő saját személyére vonatkozó kompetenciái

- a szociális kompetencia

- az érzelmi-indulati kompetencia

- a motorikus kompetencia

- a kognitív kompetencia

- a kreatív kompetencia

- a figyelem kompetenciája.

A kisiskoláskori idegennyelv-tanításban az interkulturális kompetencia fejlesztésénél építhetünk a más emberekhez füződő társas kapcsolat nevelési vonatkozásaira, illetve az idegen nyelven való érintkezés kommunikatív aspektusaira is. A gyermekek interkulturális kérdések iránti érdeklődését többféleképpen is felkelthetjük ebben az életkorban (Widlok, 2010. 26. o.):

\footnotetext{
${ }^{2}$ A programcsomag kidolgozásában részt vettek az Oktatási Minisztérium Idegen Nyelvi Csoportjának általános iskolai szakértői: Bors Lídia, Jilly Viktor, Kovács Judit, Morvai Edit, Szilágyiné Hodossy Zsuzsanna, Trentinné Benkő Éva.
} 
- országismereti tartalmak segítségével a célnyelvi kultúra iránt (például ünnepek és szokások), valamint az 'idegen' és a saját kultúra eltérő vonásai iránt,

- a más kultúrából származó emberek iránti empátia elmélyítését szolgáló anyagokkal,

- olyan életből vett helyzetekkel (szerepjátékokkal), amelyek segítségével gyakorolni lehet az interkulturális szituációkban való cselekvést.

Minden tanuló más-más tanulótípushoz tartozik, de a megfelelő tanulási stratégiák alkalmazásával mindenki sikeres (nyelv)tanulóvá válhat. A tanulási stratégiák ugyanis megkönnyítik az idegen nyelv tanulásának folyamatát (is) és pozitív beállítódáshoz vezetnek az idegen nyelv tanulásával és használatával szemben. Ezért érdemes már a nyelvoktatás kezdeti szakaszában is a tanulás tartalmait és módszereit úgy kialakítani, hogy a tanulóknak lehetősége legyen önmaguk és tanulási viselkedésük megfigyelésére, saját tanulótípusuk felismerésére, és így az eredményes (nyelv)tanulás megalapozására (Widlok, 2010. 27. o.).

\subsection{A kisiskoláskori idegennyelv-oktatás tartalma}

A kisgyermekkori idegennyelv-tanulás egyik sajátossága, hogy a természetes nyelvelsajátítás folyamataira épül. A gyermekek számukra érdekes, értelmes, önmagukban motiváló és kognitív szintjüknek megfelelő, kihívást jelentő tevékenységekben vesznek részt. Ezek során a célnyelvet hallva, a szituációt, a kontextust értve haladnak előre a nyelv elsajátításában. Ez a folyamat lassú, az idősebb korosztályra jellemző látványos nyelvi eredményt nem várhatunk. Egyik tipikus jellemzője a csendes szakasz, melynek során egyes tanulók akár hónapokig sem szólalnak meg, de a játékos tevékenységekbe szívesen bekapcsolódnak (vö. NAT, 2007, 2012; Kerettanterv, 2004, 2012).

Az idegennyelv-órákon a gyermekek a számukra még ismeretlen nyelven hallottakat a világról kialakult ismereteik alapján értelmezik, ezért elengedhetetlen, hogy a tananyag általuk ismert tartalmakra épüljön. Ez egyrészt a konkrét szituációk kihasználásával, szemléltetéssel, másrészt az óvodában, illetve a más tanórákon szerzett ismeretek integrálásával érhető el. Így válik a célnyelvi tanári beszéd érthetővé a tanulók számára (vö. NAT, 2007, 2012; Kerettanterv, 2004, 2012; Kuti et al., 2004. 7. o.; Widlok, 2010. 28. o.).

Az 1-3. évfolyam számára kifejlesztett idegen nyelvi program az alábbi témaköröket ajánlja (Kuti et al., 2004. 7. o.):

- Én és a családom,

- Otthonom,

- Étkezés,

- Öltözködés,

- Iskolám, barátaim,

- Én és az állatok,

- Kedvenc időtöltésem,

- Ünnepek, szokások.

Widlok (2010. 28. o.) hangsúlyozza, hogy a tartalmakat lehetőség szerint autentikus tananyagok segítségével közvetítsük. Erre a dalok, mondókák, versek, mesék és történetek a legalkalmasabbak ebben az életkorban. Kuti és munkatársai (2004. 8-9.) is a kisiskoláskori idegennyelv-oktatás fontos elemeként említi az autentikus dalok, mondókák, kiszámolók, körjátékok és társasjátékok, illetve az egyszerü, képes történetek köré füzhető tevékenységeket. 


\subsection{A kisiskoláskori idegennyelv-oktatás ajánlott tevékenységformái}

A tanulók életkori sajátosságából adódik, hogy a kisiskoláskori idegennyelv-tanításban minden olyan cselekvésorientált oktatási kínálat célravezető, ahol a tanulók játékos keretek között sajátítják el a tartalmakat, lehetőségük van a kísérletezésre, a mozgásra és kreativitásuk fejlesztésére. Kuti és munkatársai (2004. 9. o.) öt tevékenységformát sorolnak fel, melyek sikeresen alkalmazhatók az adott célcsoportnál:

1. a szóbeli utasításokra adott testi válaszok,

2. a hagyományos és eredeti (autentikus) mondókák, kiszámolók, dalok, körjátékok és társasjátékok,

3. egyszerü, képes történetek feldolgozása a tanulók aktív bevonásával,

4. kereszttantervi tartalmak alkalmazása,

5. idegen nyelvi kirándulások a tantermi kereten túl.

A szóbeli utasításokat kezdetben a tanár adja, de idővel egy-egy önként vállalkozó tanuló átveheti ezt a szerepet, és akkor nemcsak a tanulók beszédértése, de beszédkészsége is fejlődik. A szóbeli utasítások részben a tanórával kapcsolatosak (Állj fel!, Ülj le!, Nyisd ki az ablakot! stb.), de bármilyen egyéb mozgásra is irányulhatnak (Táncolj!, Ugorj!, Gitározz! stb.) vagy utánzásra késztethetnek (Úgy mozogj/ beszélj, mint egy ...!) Ezzel a tevékenységi formával a tanulók nagy mozgásigényét is kielégíthetjük.

Az autentikus szövegek (dal, vers, mondóka, mese) feldolgozása egyrészt fejleszti a tanulók kommunikatív kompetenciáját, másrészt fontos országismereti tudnivalókat is közvetít a célnyelvi ország lakóiról és kultúrájáról, ezzel fejlesztve a tanulók interkulturális kompetenciáját. Azok a dalok, mondókák, versek, játékok a leghatékonyabbak, amelyeket valamilyen cselekvés kísér, mert így a tanulók több csatornán keresztül ismerkedhetnek az új tartalommal.

Idegennyelv-órán lehetőség van arra, hogy a más tanórákon szerzett ismereteket is hasznosítsuk. Kuti és munkatársai (2004. 9. o.) a matematika, a rajz és vizuális kultúra, technika és életvitel, ének-zene, matematika, testnevelés és sport tantárgyakat említi lehetséges kapcsolódási pontként. A Kerettanterv (2012) az ajánlott témaköröknél minden esetben utal a kereszttantervi kapcsolódási pontokra. A 4. évfolyam esetében ezek a környezetismeret, matematika, ének-zene, vizuális kultúra, illetve a dráma és tánc. Mivel azonban az alsóbb évfolyamokon is hasonló tevékenységek (rajzolás, színezés, hajtogatás, daltanulás, ritmushangszerek használata, mérés, csoportosítás, érzékelést, mozgást és beszédet fejlesztő játékok, fogójátékok stb.) jellemzik az idegennyelv-oktatást, véleményem szerint a felsorolt tantárgyakkal az 1-3. évfolyam idegennyelv-tanításánál is felfedezhetők a kapcsolódási pontok.

Idegen nyelvet nemcsak az iskola falain belül tanulhatunk. Globalizálódó világunkban nap mint nap számos lehetőség nyílik arra, hogy hétköznapi tevékenységeink során találkozzunk valamilyen idegen nyelvvel. Ez a tevékenységforma azonban elsősorban az olvasás bevezetése után valósítható meg.

\subsection{A kisiskoláskori idegennyelv-oktatás eszközei, médiumai}

A kisiskoláskori idegennyelv-oktatásban felhasználható eszközökkel, médiumokkal kapcsolatban fontos megjegyezni, hogy a 6-9 éves gyermekek a tanuláshoz előszeretettel választanak a közvetlen környezetükböl, illetve a természetből vett valóságos tárgyakat, valamint szívesen használnak játékeszközöket, kézre húzható babát. A kézre húzható baba az első órától kezdve fontos eleme a kisiskoláskori idegennyelv-oktatásnak, mert ő képviseli az adott idegen nyelvet a nyelvórán egyfajta 
native speakerként. Ő csak az adott idegen nyelven beszél és ért, ezért a gyermekek igyekeznek minél több kifejezést elsajátítani, hogy kommunikálhassanak vele. Sok gyermek számára könnyebb a babával, mint a tanárral beszélni az idegen nyelven. A baba segítségével vezetheti be a nyelvtanár az új tartalmakat. A kézre húzható baba nyelvórai alkalmazásával kapcsolatban további ötletek olvashatók Graffmann (2001) Die Puppe spielt mit címü tanulmányában.

A leggyakrabban felhasznált nyomtatott eszközök közé tartoznak a képes, valamint szókártyák, a képeskönyvek, továbbá a tankönyvcsaládok, folyóiratok, fóliák, poszterek vagy filmek, CD-ROM-ok, az interneten található anyagok és az e-mail. A szóbeli kezdőszakaszban az említett eszközök közül azok használhatók fel, amelyekhez nincs szükség az olvasás- és íráskészségre.

\subsection{A kisiskoláskori idegennyelv-oktatás fejlesztési követelményei}

Az említett sajátosságok a fejlesztési követelményekben is tükröződnek. A tanulók a negyedik évfolyam végére elért nyelvi szintje KER-szintben nem adható meg, de a Kerettanterv (2012) értelmében a ciklus végén az alábbi fejlesztési eredmények várhatók:

\section{A tanuló}

- aktívan részt vesz a célnyelvi tevékenységekben,

- követi a célnyelvi óravezetést, az egyszerü tanári utasításokat,

- megérti az egyszerü, ismerős kérdéseket, válaszol ezekre,

- kiszüri egyszerü, rövid szövegek lényegét,

- elmond néhány verset, mondókát és néhány összefüggő mondatot önmagáról,

- minta alapján egyszerü párbeszédet folytat társaival,

- ismert szavakat, rövid szövegeket elolvas és megért jól ismert témában,

- tanult szavakat, ismerős mondatokat lemásol,

- minta alapján egyszerü, rövid szövegeket alkot.

Mivel vizsgálódásunk középpontjában a szóbeli kezdőszakasz, azaz az olvasás és írás bevezetése előtti szakasz áll, válasszuk ki a fenti felsorolásból az erre a speciális célcsoportra vonatkoztatható várható eredményeket, tehát azokat, amelyek a beszédértés, illetve a beszédkészség fejlesztésével kapcsolatosak. Ennek tükrében megállapíthatjuk, hogy a tanulók a szóbeli kezdőszakasz végére várhatóan

- aktívan részt vesznek a célnyelvi tevékenységekben,

- követik a célnyelvi óravezetést, az egyszerü tanári utasításokat,

- megértik az egyszerü, ismerős kérdéseket, válaszolnak ezekre,

- kiszürik egyszerü, rövid (hallott) szövegek lényegét,

- elmondanak néhány verset, mondókát és néhány összefüggő mondatot önmagukról,

- minta alapján egyszerủ párbeszédet folytatnak társaikkal.

Összegezve megállapíthatjuk, hogy bár a kisiskoláskori idegennyelv-tanítás elsődleges célja a kommunikatív kompetencia fejlesztése, teret kell biztosítani a nyelvórán az általános, az interkulturális és a tanulásstratégiai készségek fejlesztésének is. Ennél a korosztálynál nagy szerepet játszik a cselekvésorientáltság, a játékosság, a mozgás.

Mivel a tanulási folyamat során a tanuló egész személyisége formálódik, alapvető fontosságú, hogy a kisgyermekkori idegennyelv-tanítást (is) áthassa a holisztikus szemlélet, ezért bírnak nagy jelentőséggel a kereszttantervi kapcsolódási pontok is, így többek között a drámapedagógiai tevékenységek alkalmazása az idegennyelv-órán. A következő fejezetben konkrét példák segítségével vizsgáljuk meg, hogyan ötvözhető a drámapedagógia és a kisiskoláskori idegennyelv-oktatás a szóbeli kezdőszakaszban. 


\section{Dramatikus tevékenységek lépésröl lépésre}

Mint azt Marlok (2005. 5. o.) is hangsúlyozza, a dramatikus tevékenységek nyelvtanításban való alkalmazása a német és az angol nyelv vonatkozásában jelentős eltérést mutat. Míg angol nyelven számos könyv jelent meg a témában, a német szakirodalom lényegesen szegényebb. Két nevet azonban mindenképp fontos megemlíteni: Manfred Schewe és Elektra Tschelikas. Schewe (1993) volt az első Németországban, aki összekötötte a nyelvtanítás módszertani ismereteit a drámapedagógia elméletével, és ezáltal egy úffajta nyelvtanítási elméletet fejlesztett ki, melyet Fremdsprachen inszenieren. Zur Fundierung einer dramapädagogischen Lehr- und Lernpraxis címü könyvében írt le. Tschelikas (1999) könyve (Dramapädagogik im Sprachunterricht) gyakorlati segítséget nyújt a téma iránt érdeklődő nyelvtanároknak német nyelven. Véleménye szerint a nyelvórákon olyan helyzeteket (Sprachnotsituationen) kell teremteni, ahol a tanulóknak kommunikálniuk kell, azaz egyfajta rögtönzésben látja a dráma erejét, lehetőségét a nyelvórán.

Schewe (1993. 185. o.) szerint akkor beszélhetünk kommunikatív nyelvoktatásról, ha a nyelvórán dramatikus tevékenységeket alkalmazunk. Felmerül a kérdés, mely dramatikus tevékenységek alkalmazhatók eredményesen a kisiskoláskori idegennyelv-oktatás szóbeli kezdőszakaszában. Bolton (1993. 12. o.) szerint az iskolákban megjelenő föbb drámaformák az 1. fejezetben bemutatott „A”, „B” és „C” típusú dramatikus tevékenységek, melyeket a "gyermekek és fiatalok számára megajánlott" drámának nevez, szolgálhatják a „D” típusú dramatikus tevékenységet, azaz a tanítási drámát. A továbbiakban vizsgáljuk meg, megvalósítható-e a tanítási dráma, illetve a Takács által „E” és „F” típusú drámának nevezett dramatikus tevékenységek a kisiskoláskori idegennyelv-oktatás szóbeli kezdőszakaszában!

A németórán alkalmazható dramatikus tevékenységek bemutatásánál a nyelvóra fázisait vettem alapul. Cros (1993. 5. o.) négy szakaszt különböztet meg a kisiskoláskori idegennyelvórán:

1. Neues einführen (Az új anyag bevezetése)

2. Vertiefen (Mélyítés)

3. Ergebnisse sichern (Rögzítés)

4. Entspannen (Levezetés)

Cros (1991. 7. o.) fontosnak tartja, hogy minden órának legyen egy 'kerete': a foglalkozás elején a gyermekek egymás kezét fogva körben állnak és egy dalt énekelnek, vagy verset mondanak el közösen. A kör az egységet szimbolizálja: nincs kezdete és nincs vége. Minden résztvevő egyenlő. $A$ foglalkozás végén ismét körbe állnak, megfogják egymás kezét és búcsúzóul ismét közösen énekelnek, vagy elmondják a tanult versikét.

A drámafoglalkozások felépítését Moreno csoportüléseihez hasonlóan három nagy szakaszra oszthatjuk (Pinczésné, 2003. 21. o.):

1. warm up (involvációs vagy bevezető szakasz)

2. action (a dramatizálás, a játék szakasza)

3. sum up (befejező fázis).

Ha a kétféle felosztást összevetjük, megállapithatjuk, hogy a warm up szakasznak az új anyag bevezetése, az action résznek a mélyítés és rögzítés, míg a sum up szakasznak a levezetés feleltethető meg. Ezért tanulmányomban a drámafoglalkozások triadikus szisztémájára építve mutatom be a kisiskoláskori idegennyelv-oktatás kezdő szakaszában alkalmazható drámapedagógiai tevékenységeket. 


\subsection{Warm up}

A warm up a kezdő fázis, melynek célja a ráhangolás, a megfelelő légkör megteremtése. A holisztikus nevelés szellemében ebben a szakaszban nemcsak az értelmet, de a testet, a lelket és a hangot is megszólítjuk. Ez a fázis elengedhetetlenül szükséges ahhoz, hogy a foglalkozás fő részét képező játékban a gyermekeknek az adott szerepekkel, helyzetekkel kapcsolatban legyenek elképzeléseik.

A foglalkozás elején ezért célszerű a Bolton által „A típusú” dramatikus tevékenységeknek nevezett gyakorlatok közül választani. Ezek lehetnek bemelegítő, lazító gyakorlatok, az érzékelés, a koncentrációkészséget vagy a kreativitást fejlesztő gyakorlatok. A kezdő szakaszban alkalmazhatunk mimikai, empátiás, metakommunikációs, mimetikus vagy a színpadi beszédet fejlesztő gyakorlatokat is. A gyakorlatok kiválasztásánál, illetve a gyakorlatsor összeállításánál a legfontosabb szempont, hogy a fő rész játékára készítse elő a játszókat.

Az első foglalkozás mindig különleges alkalom, egyfajta névjegykártya. A gyermekek betekintést nyernek a drámapedagógia 'boszorkánykonyhájába', és sok esetben már itt eldől, sikerül-e megnyernünk őket. Ezért véleményem szerint az első foglalkozáson kell megalapozni egyfajta, a későbbi drámafoglalkozásokra is érvényes szokás- és szabályrendet.

Az első alkalom elsődleges célja, hogy megismerjük egymást, megtanuljuk egymás nevét, ezért célszerü a foglakozást centrálisan, a névtanulós játékok köré építeni.

A kisiskoláskorban különösen fontos a keretek, az órai rutin kialakítása. Ebben segít az a dal is, amit a legelső foglalkozáson ismernek meg és játszanak el a gyermekek, illetve amivel a későbbi foglalkozásokat is kezdjük. A dal egy ismert német gyermekdal, ami nemcsak a „Guten Tag!” köszönési formát vezeti be, de tartalmaz néhány fontos, könnyen eljátszható mellékneveket is: groß (nagy), klein (kicsi), dick (kövér), dünn (vékony). A dalok autentikus szövegek, melyek segítségével a gyermekek betekintést nyernek az adott célnyelvi ország kultúrájába, és játszva sajátíthatnak el összetettebb nyelvi elemeket (szókincs, nyelvtani struktúrák) is. A dal mozgásos megjelenítése egyfajta mimetikus játék, amely nemcsak a szókincset, de a nonverbális kifejezőkészséget is fejleszti. Mivel el is játsszuk, amit énekelünk, a gyermekekhez több csatornán keresztül jut el az információ, ezáltal jobban rögzül, illetve a különböző tanulótípusok is megtalálhatják a nekik megfelelő tanulási stratégiát.

A tanulásnál fontos az ismétlés. Ez azonban egy elég monoton, ezáltal unalmassá váló folyamat. Hogy ezt megelőzzük, a dalt mindig másképp (halkan; cérnavékony hangon, mint egy kisegér; mély, öblös hangon, mint egy medve; vidáman; szomorúan; fáradtan; a játszók egyéni ötletei alapján) énekeljük el. Az éneklés módjának változtatása nemcsak motiváló, de fejleszti a beszédkészséget is.

A drámafoglalkozásokon fontos szerepet kap a színpadi beszéd fejlesztése is. Ez különösen igaz az idegen nyelvű drámajátékra, ahol az anyanyelvtől eltérő kiejtést és intonációt is gyakorolni kell. Mivel a kisiskolás korosztály különösen fogékony a helyes kiejtés elsajátítására, elengedhetetlenül szükséges a beszédgyakorlatok beépítése a foglalkozásba. A célcsoport életkori és nyelvi sajátosságait figyelembe véve legeredményesebben játékos gyakorlatokkal, dalokkal, nyelvtörőkkel gyakoroltathatjuk a helyes kiejtést és intonációt.

\subsection{Action}

Az action a drámafoglalkozás fő része. Ebben a szakaszban kerül sor a játékra, a dramatizálásra, ezért elsősorban a Bolton által „B típusú” dramatikus tevékeny- 
ségek, azaz a dramatikus játékok kapnak főszerepet. Mint a „B típus” bemutatásánál már említettem, a dramatikus játékok nyitott kimenetelü, szerkesztetlen improvizációk, ahol a gyermekek szerepben vannak.

\subsubsection{Improvizáció}

Ami az improvizációk világát illeti, ennél a célcsoportnál még csak az első 'ujjgyakorlatokról' beszélhetünk. Mint azt Gabnai is említi (2005. 119. o.), a dramatikus improvizációnak két fajtája van: a némajáték és a szöveges rögtönzés.

A némajátékot Gabnai (2005. 122. o.) „kihagyhatatlan előiskolaként” jellemzi, amelyhez a játékosoknak pontos testtudattal kell rendelkezniük. Ezt a célt szolgálják az ezt megelőző előkészítő gyakorlatok, a ritmusgyakorlatok és a tánc. Gabnai (2005. 121. o.) arra is felhívja a figyelmet, hogy „tulajdonképpen minden alkalmas arra, hogy dramatikus rögtönzést indítson el, de figyelembe kell vennünk a csoport érettségét, problémaérzékenységét és érdeklődési körét". Másik megszívlelendő tanácsa, hogy hívjuk fel a figyelmet a mozgás elsődlegességére a drámai akciók során (Gabnai, 2005. 121. o.).

A célcsoport még nagyon csekély produktív szókinccsel rendelkezik, ezért a szöveges improvizációk esetén a halandzsanyelvet, illetve a számbeszédet célszerü választani.

Minden improvizáció előtt ki kell jelölni a játékteret, és el kell mondani, mikor kezdődik és mikor ér véget egy-egy jelenet (például taps). A játék alatt mind a játszók, mind a nézők figyelmét fel kell hívni arra, hogy ne essenek ki a szerepükből, ha erre szükség van. Csak akkor állítsuk meg a jelenetet, ha valaki nem látszik jól, vagy a közönségnek háttal játszik. A jelenetet egyébként akkor állítjuk le, ha a nézők számára világossá vált, ki, mit és miről játszik, illetve hogyan oldották meg a problémát a játszók. Minden jelenet után beszéljük meg a tanulók nyelvi szintje miatt kezdetben még magyarul, kik, mit és miről játszottak, hogyan oldották meg a problémát a játszók. Arra is térjünk ki a megbeszélésnél, meddig sikerült elöre egyeztetniük, és honnan kellett valóban improvizálniuk a játszóknak.

A fö részben az improvizációkon kívül a közös dramatizálás is lehetséges cél az adott célcsoportnál.

\subsubsection{A közös dramatizálás első lépései}

A közös dramatizálás egy hosszabb folyamat, melyhez Gabnai (2005. 175-178.) az alábbi lépéseket javasolja:

1. Előkészítés

2. A kiválasztott mü közös megvitatása

3. Cselekményváz némajátékkal

4. Jelenetek némajátékkal

5. Jelenetek szöveggel

6. A jelenetek összefüzése

7. Zenei és látványelemek

8. Javítópróbák

A közös dramatizálásnál először tisztázni kell, miröl szól nekünk a kiválasztott mü, illetve miről szólhat másoknak, ezért a fö rész elején vitassuk meg a történetet. A gyermekek nyelvi szintje miatt ez a megbeszélés anyanyelven történik. Ebben a szakaszban kerül sor a kihagyhatatlan szerepek, illetve a többszörözhető és az újonnan megalkotott figurák, valamint a helyszínek kijelölésére. 
A cselekményváz összeállítását segíti elő az ún. tablótechnika. Ez a munkaforma megkívánja a játszóktól, hogy a mese vagy a történet lényegét emeljék ki. A tablókkal történő játék során a játszók kijelölik a mese fordulópontjait, csomópontjait is, melyek azok a részek, amelyek elhagyhatatlannak tűnnek a későbbi játékból, azaz megjelenítik a mese cselekményvázát némajátékkal. A tablókhoz csoportokba osztjuk a játszókat. A csoportok először egy-egy állóképben (tabló) megjelenítik a történet legfontosabb mozzanatait. A többi csoport tagjai nézik a tablókat, és azután megbeszéljük, mi volt jó, mi maradt ki, mi nem volt egyértelmű, min lehetne/kellene változtatni.

Ezután kerül sor a jelenetek kidolgozására, először némajátékkal. A jeleneteknél fontos tudatosítani a játszókban, hogy minden jelenetnek van eleje, közepe és vége. A jelenetekhez új csoportokat alakítunk. A csoportok egy-egy jelenetet játszanak el némajátékkal. A csoport maga választja ki, ki és hogyan indítja, illetve fejezi be a jelenetet. Ha szükséges, a játék alatt mind a játszók, mind a nézők figyelmét hívjuk fel arra, hogy ne essenek ki a szerepükből, ne beszéljenek, kuncogjanak stb. A jelenetet csak akkor állítsuk meg, ha valaki nem látszik jól, vagy a közönségnek háttal játszik. $A$ látottak megbeszélése ugyanúgy zajlik, mint az előző lépésnél.

A következő foglakozásokon nyílik mód arra, hogy megfelelő szöveget találjunk a jelenetekhez. Mivel a játszók nyelvi szintje még nagyon alacsony, fontos szerep jut az egyszavas szövegeknek és a nonverbális eszközöknek. Ezután tudjuk összefüzni a jeleneteket, illetve zenei és látványelemekkel is színesíthetjük a közös dramatizálásunk eredményét.

A fenti példa is mutatja, hogy már egy mind a drámapedagógiában, mind az idegennyelv-elsajátításában kezdő csoportnál is megtehetjük az első lépéseket a Bolton által „C típusú” dramatikus tevékenységnek nevezett színház felé.

\subsection{Sum up}

A drámafoglalkozás fontos eleme a befejező, sum up fázis. Mint Pinczésné (2003. 21. o.) is hangsúlyozza, ez „egy igazán hatékony szakasz”, ahol föleg csoportmegbeszélés keretében nyílik lehetőség a játék élményének elemzésére. A csoportmegbeszélés abban is segít, hogy kilépjünk a felvett szerepből. Ez különösen a fiatalabb korosztálynál fontos, akik nehezebben tudnak különbséget tenni a fiktív és a valós világ között.

Ebben a szakaszban alkalmazhatjuk az ún. reflektív jellegű konvenciókat is, melyek a drámai tartalom utólagos újragondolását segítik. Ezek a konvenciók (a pillanat megjelölése, gondolatkövetés, narráció stb.) lehetővé teszik a szereplők gondolatainak megismerését (vö. Kaposi, Lipták és Mészáros, 2008. 58. o.). A gyermekek reflexiói a drámapedagógust is segítik a további tervezési folyamatban.

A foglalkozást ajánlatos valamilyen levezető, lazító gyakorlattal zárni. Ez lehet játék, amit a témának megfelelően adaptáltunk, fantáziautazás, amivel végigjárjuk a foglalkozás legfontosabb állomásait, vagy egy dal.

\section{Összegzés}

Tanulmányomban azt vizsgáltam, hogyan alkalmazható a drámapedagógia a kisiskoláskori idegennyelv-tanítás egyik speciális fázisában, az ún. szóbeli kezdőszakaszban, ahol a tanulók még az idegen nyelvű olvasás és írás bevezetése előtt állnak. Láttuk, hogy a dramatikus tevékenységek nyelvtanításban való alkalmazása a német nyelv vonatkozásában kevésbé terjedt el, mint az angol nyelv esetében, de mindenképpen meg kell említeni Manfred Schewe nevét, aki szerint akkor beszélhetünk kom- 
munikatív nyelvoktatásról, ha a nyelvórán dramatikus tevékenységeket alkalmazunk (Schewe, 1993. 185. o.). Ezért először azt vizsgáltam, mik tartoznak a dramatikus tevékenységek körébe, és hogyan rendszerezhetőek az említett tevékenységek (vö. Bolton, 1994; Takács, 2008).

A kisiskoláskori idegennyelv-tanítás a nyelvoktatás egy speciális területe, melynek sajátosságait (cél, tartalom, ajánlott tevékenységi formák, eszközök, médiumok, fejlesztési követelmények) feltétlenül ismerni kell ahhoz, hogy meghatározhassuk, mely dramatikus tevékenységek alkalmazhatók eredményesen az adott célcsoportnál. Mivel a NAT $(2007,2012)$ nem fogalmaz meg konkrét fejlesztési követelményeket az 1-3. évfolyam idegennyelv-tanításával kapcsolatban, a témakör bemutatásához a Világ-Nyelv Programban 2004-ben kidolgozott ajánlást (Kuti et al., 2004), illetve a korai nyelvoktatással foglalkozó ún. Nürnberger Empfehlungen átdolgozott változatát (Widlok, 2010) vettem alapul.

A harmadik rész azoknak a drámafoglalkozásokra jellemző három nagy szakasz (warm up, action, sum up) alapján csoportosított dramatikus tevékenységeknek a bemutatását és leírását tartalmazza lépésről lépésre, melyek sikerrel alkalmazhatóak a korai idegen nyelvi fejlesztésben.

Véleményem szerint bármely tantárgy esetében különösen nagy jelentőséggel bír a legelső óra/foglalkozás, mert ez alapozza meg a tanulók későbbi attitüdjét, motivációját az adott tantárgy iránt. Ezen kívül az első foglalkozáson több olyan tevékenységi formát ismerhetnek meg a tanulók, amelyek (esetleg kis módosítással) a későbbi órák állandó elemévé válnak (például Guten-Tag-Lied, körben állás/ülés, készségfejlesztő játékok).

A helyes (színpadi) beszéd fejlesztésének első lépéseit is megalapozhatjuk a korai idegen nyelvi fejlesztés során.

A tanulók megismerkedhetnek a néma és szöveges improvizáció lehetőségeivel, illetve a közös dramatizálás módszerével is. Idegen nyelv esetén az improvizáció két fajtája közül a némajáték alkalmazása felel meg jobban a tanulók nyelvi sajátosságainak, de a szöveges rögtönzés egy-egy egyszerübb formája is megvalósítható (számbeszéd, halandzsa).

A sum up szakasz nagyon fontos, különösen a kisebb gyermekek esetében, akik nehezebben tesznek különbséget a fiktív és a valós világ között. A foglalkozás végén ezért minden esetben biztosítanunk kell a lehetőséget arra, hogy a választott szerepükből kilépjenek a játszók, reflektáljanak az átélt élményekre és visszatérjenek a valóságba.

A bemutatott példák jól szemléltetik, hogy a gyermekek a dramatikus tevékenységek legtöbb típusával találkozhatnak. Az „A” típusú gyakorlatok közé tartozó szabályjátékok és helyzetgyakorlatok képezik a későbbi munka alapjait, így természetesen szerves részét képzik a foglalkozásoknak. A megismert játékok és gyakorlatok fejlesztik a tanulók primer nyelvi készségeit, memóriáját, bővítik szókincsüket, fonetikai ismereteiket. A „B” típusú dramatikus játékok is megvalósíthatók, csak a nyelvi sajátosság miatt a nonverbális kifejezőkészségnek nagyobb szerep jut az adott célcsoportnál. A „C” típusú dramatikus tevékenység, a színház is megvalósulhat egy-egy közönségnek tartott bemutató keretein belül. A közös előadás nemcsak a beszédkészséget, de a szociális kompetenciát is fejleszti. A „D” típusú tanítási dráma, illetve a Takács által említett „E” típusú szakértői dráma még nem releváns az adott körülmények között, de az „F” típusú színházi nevelés egy-egy eleme már megtalálható ebben a korai szakaszban is (például konvenciók alkalmazása).

A szóbeli kezdőszakasz minden kisiskoláskori idegennyelv-tanítás kezdetén fontos fázis. Időtartama a kezdés időpontjától függően eltérő hosszúságú lehet: egy-két héttől akár egy-két évig is tarthat. Tanulmányomban olyan dramatikus tevékenységeket 
mutattam be, melyek eredménnyel alkalmazhatóak a szóbeli kezdőszakaszban. A tevékenységek alkalmazásánál előny a drámapedagógus végzettség, hiszen így tudatosabb egy-egy gyakorlat, játék alkalmazása, de véleményem szerint olyan nyelvtanárok is alkalmazhatják, akik nem rendelkeznek ezzel a végzettséggel, de nyitottak a dráma nyújtotta lehetőségek iránt, és szeretnék továbbfejleszteni, színesíteni tanári eszköztárukat.

\section{Felhasznált irodalom}

Bolton, G. (1994): A tanítási dráma elmélete. Marczibányi Téri Művelődési Központ, Budapest. Cros, R. (1993): Ein Elefant auf dem Spinnennetz. Unterrichtsphänomene frühen Fremdsprachenlernens. Begleitbroschüre zur Unterrichtsdokumentation der Kinderkurse am Goethe-Institut in Bordeaux. Goethe Institut, München.

Czike Bernadett. (2012): Saját élményű pedagógusképzés. Gondolat Kiadó, Budapest.

Gabnai Katalin (2005): Drámajátékok. Bevezetés a drámapedagógiába. Helikon, Budapest.

Graffmann, H. (2001): Die Puppe spielt mit. Handpuppen im Deutschunterricht. Fremdsprache Deutsch, 5., 50-54.

Kaposi László (2002, szerk.): Játékkönyv. Színházi füzetek IV. Kerekasztal Színházi Nevelési Központ, Marczibányi Téri Művelődési Központ, Budapest.

Kaposi László (2008): Mi a dráma és mi nem az? Dráma és színház. In: Lipták Ildikó (szerk.), Tanítási dráma. Drámapedagógia a hátrányos helyzetü tanulók integrált nevelésének szolgálatában. Segédlet tanfolyami hallgatók számára. Educatio Társadalmi Szolgáltató Közhasznú Társaság, Budapest, 2-6.

Kaposi László, Lipták Ildikó és Mészáros Beáta (2008): Konvenciók. In: Kaposi László, Lipták Ildikó és Mészáros Beáta Tanítási dráma. A drámapedagógia a hátrányos helyzetü tanulók integrált nevelésének szolgálatában. Segédlet a pedagógusképzés hallgatói számára. Educatio Társadalmi Szolgáltató Közhasznú Társaság, Budapest, 37-39.

Kuti Zsuzsa, Bors Lívia, Jilly Viktor, Kovács Judit, Morvai Edit, Szilágyiné Hodossy Zsuzsanna és Trentinné Benkő Éva (2004): Idegen Nyelvi Program az 1-3. évfolyam számára. Ajánlás a 6-9 éves korosztály idegennyelv-tanitásához. Világ-Nyelv Program. Oktatási Minisztérium, Nemzetközi Államtitkárság, Idegen Nyelvi Csoport, Budapest. 2004. június.

URL: http://www.nefmi.gov.hu/nemzetkozi-kapcsolatok/archivum/vilag-nyelvprogram-090803-11. Letöltés ideje: 2014. 07. 24.

Közös Európai Referenciakeret (2002): Oktatási Minisztérium, Budapest.

Marlok Zsuzsa (2005): Drámatechnikák alkalmazása a nyelvtanárképzésben és -továbbképzésben. DPM, 1., 4-8.

Pinczésné Palásthy lldikó (2003): Dráma, pedagógia, pszichológia. Pedellus, Debrecen.

Schewe, M. (1993): Fremdsprache inszenieren. Zur Fundierung einer dramapädagogischen Lehr- und Lernpraxis. Carl von Ossietzky Universität, Oldenburg.

Sz. Pallai Ágnes (2003): Mégiscsak színház?! Az angol drámapedagógia történetéből. Iskolakultúra, 11., 83-90.

Szabó-Thalmeiner Noémi (2011): Drámapedagógia. URL: www.bbtepedsm.ro/letoltheto/Dramapedagogia2009.doc Letöltés ideje: 2014. 07. 24.

Takács Gábor (2008): A dramatikus tevékenység rendszerezése. In: Lipták Ildikó (szerk.), Tanítási dráma. Drámapedagógia a hátrányos helyzetü tanulók integrált nevelésének szolgálatában. Segédlet tanfolyami hallgatók számára. Educatio Társadalmi Szolgáltató Közhasznú Társaság, Budapest, 32-37.

Tselikas, E. (1999): Dramapädagogik im Sprachunterricht. Orell Füssli Verlag AG., Zürich.

Widlok, B. (2010, szerk.): Nürnberger Empfehlungen zum frühen Fremdsprachenlernen Neubearbeitung. Goethe Institut, München.

\section{Rendeletek, törvényi hivatkozások}

110/2012. (VI. 4.) Korm. rendelet a Nemzeti alaptanterv kiadásáról, bevezetéséről és alkalmazásáról. 
17/2004. (V. 20.) OM rendelet a kerettantervek kiadásának és jóváhagyásának rendjéről, valamint egyes oktatási jogszabályok módosításáról.

243/2003. (XII. 17.) Korm. rendelet a Nemzeti alaptanterv kiadásáról, bevezetéséről és alkalmazásáról.

51/2012. (XII. 21.) EMMI rendelet a kerettantervek kiadásának és jóváhagyásának rendjéről. 2011. évi CXC. törvény a nemzeti köznevelésröl. Magyar közlöny 2011/162. 